\title{
The effect of Light Emitting Diode electric toothbrush on gingivitis: a randomized controlled trial
}

\author{
Sung-Jo Lee* \\ Department of Periodontology, College of Dentistry, Dankook University, Cheonan, Republic of Korea
}

Purpose: The aim of the present study was to compare clinical antiplaque and antigingivitis effect between Light Emitting Diode (LED) electronic toothbrush and electronic toothbrush without LED for gingivitis and mild periodontitis patients. Materials and Methods: 30 patients included in this study. 15 patients in experimental group used LED electronic tooth brush which has red and white LED within its head, and other 15 patients in control group used same product which specially modified that function without LED. Clinical parameters (Löe-Silness gingival index (GI), Quigley-Hein plaque index (PI)) were measured at the baseline, 2 weeks and 4 weeks later. Wilcoxon signed rank test and Mann-Whitney test were used for statistical analysis. Results: Compare of GI change between experimental and control group with time, both groups showed that reduced $\mathrm{Gl}$, but lower $\mathrm{Gl}$ values detected at 2 weeks and 4 weeks later in experimental group than control group. And lower PI values detected at 4 weeks later in experimental group than control group, but not statistically significant. Conclusion: Based on these results and within the limits of this study, the electronic toothbrush with LED could reducing gingivitis in a short period and infer that decreasing plaque accumulation in a long period. (J Dent Rehabil Appl Sci 2017;33(2):119-26)

Key words: toothbrushing; phototherapy; low-level light therapy; lasers

\section{Introduction}

The main cause of inflammatory periodontal disease is functions of conditionally pathogenic microflora of oral cavity. Reduction of pathogenic bacteria and plaque is needed for periodontal treatment because the susceptible host for periodontal disease is difficult to be changed. Therefore, pathogenic bacteria and plaque must be decreased to achieve successful periodontal treatment.

It has been convincingly demonstrated that longterm stability of the clinical benefits obtained by periodontal therapy can only be achieved if a cause-

*Correspondence to: Sung-Jo Lee

Clinical Fellow, Department of Periodontology, College of Dentistry, Dankook University, 119, Dandae-ro, Dongnam-gu, Cheonan, 31116, Republic of Korea Tel: +82-41-550-0263, Fax: +82-303-3442-7364, E-mail: periolee85@gmail.com Received: May 23, 2017/Last Revision: June 3, 2017/Accepted: June 9, 2017 related treatment is followed by effective periodontal maintenance care. ${ }^{1}$ Within maintenance care, it has also been demonstrated that self-performed plaque control is crucial to attain the best long-term result after the periodontal therapy. ${ }^{2}$ The daily use of a toothbrush is the most dependable way of achieving oral health benefits for all patients. For efficient plaque removal, toothbrushes vary in size and design as well as in length, hardness, and arrangement of the bristles. ${ }^{3}$

The use of low-level visible or near-infrared (IR) light from lasers for phototherapy, which is called low-level laser therapy (LLLT), has been the main-

Copyright@ 2017 The Korean Academy of Stomatognathic Function and Occlusion. (c) It is identical to Creative Commons Non-Commercial License. 
stream of phototherapy since the invention of lasers. ${ }^{4}$ But LLLT has also some limitations for personal use because of the complicated clinical setting, restrictions in wavelengths, and a limited area for light application. Besides, the narrow focal beam of lasers can be harmful for the eye and damage the tissue in our body.

Light-emitting-diode (LED) arrays were suggested for phototherapy as an effective alternative to LLLT. It was reported that the effect of light from LEDs would be same as that from lasers for therapeutic results. ${ }^{5}$ The main advantage of LEDs over lasers is that LED systems allow a larger area to be treated in a short time, with a large bandwidth (at several wavelengths), while typical laser systems irradiate only small spots. ${ }^{6}$

LEDs were applied by National Aeronautics and Space Administration (NASA) as a light source for growing plants in space stations by providing light energy for photosynthesis. NASA also found that the red part of the visible spectrum was useful for photosynthesis. Moreover, the red and IR light could also be absorbed by the human cells, modifying cellular functions, promoting cell survival, increasing the regeneration of tissue, wound healing, as well as curing inflammation and achieving pain relief. ${ }^{7-9}$

There are many previous studies about laser and LED, but the study which reported the effect of toothbrush with LED has not been reported.

The aim of the present study was to compare clinical antiplaque and antigingivitis effect between LED electronic toothbrush and electronic toothbrush without LED for gingivitis and mild periodontitis patients.

\section{Materials and Methods}

\section{Patient selection}

This study was performed at the department of periodontology, School of dental medicine, Dankook University, Korea. The study was reviewed and approved by the Institutional Review Board (IRB) of Dankook University in 2012 (IRB No. H-1203/003/ 001). To be included in this study, patients had to: have a minimum of 20 sound, natural teeth; have a negative history of antibiotic use during the preceding 2 weeks; have a mean Turesky-Quigley-Hein plaque index (PI) of at least 1.5; have a mean LöeSilness gingival index (GI) of at least 1.0. Subjects with severe periodontal disease, orthodontic appliance, removable partial denture, intraoral lesion, or systemic disease that might directly affect periodontal condition were excluded. The participant flow for the study is shown in Fig. 1, according to the Consolidated Standards of Reporting Trials (CONSORT) group statement. A total of 30 patients participated in this study and were randomly assigned in 1:1 ratio to the experimental groups and control groups, respectively. All subjects signed an informed consent after nature of the study was fully explained to them. Inclusion and exclusion criteria were shown in Table 1.

\section{Experimental material}

Experimental group used LED electronic tooth brush (PROMEDIC-2010A, PROCARE Co. Ltd., Cheonan, Korea) which has red and white LED within its head, and control group used same product

Table 1. Inclusion and Exclusion criteria

\begin{tabular}{ll}
\hline \multicolumn{1}{c}{ Inclusion criteria } & \multicolumn{1}{c}{ Exclusion criteria } \\
\hline Have more than 20 teeth & Have severe periodontal disease \\
Healthy, negative history of antibiotic use & Orthodontic appliance \\
Turesky-Quigley-Hein plaque index $(\mathrm{PI}) \geq 1.5$ & Removable partial denture \\
Löe-Silness gingival index $(\mathrm{GI}) \geq 1.0$ & Intraoral lesion \\
& Systemic disease that affect periodontal condition \\
\hline
\end{tabular}


CONSORT 2010 Flow Diagram

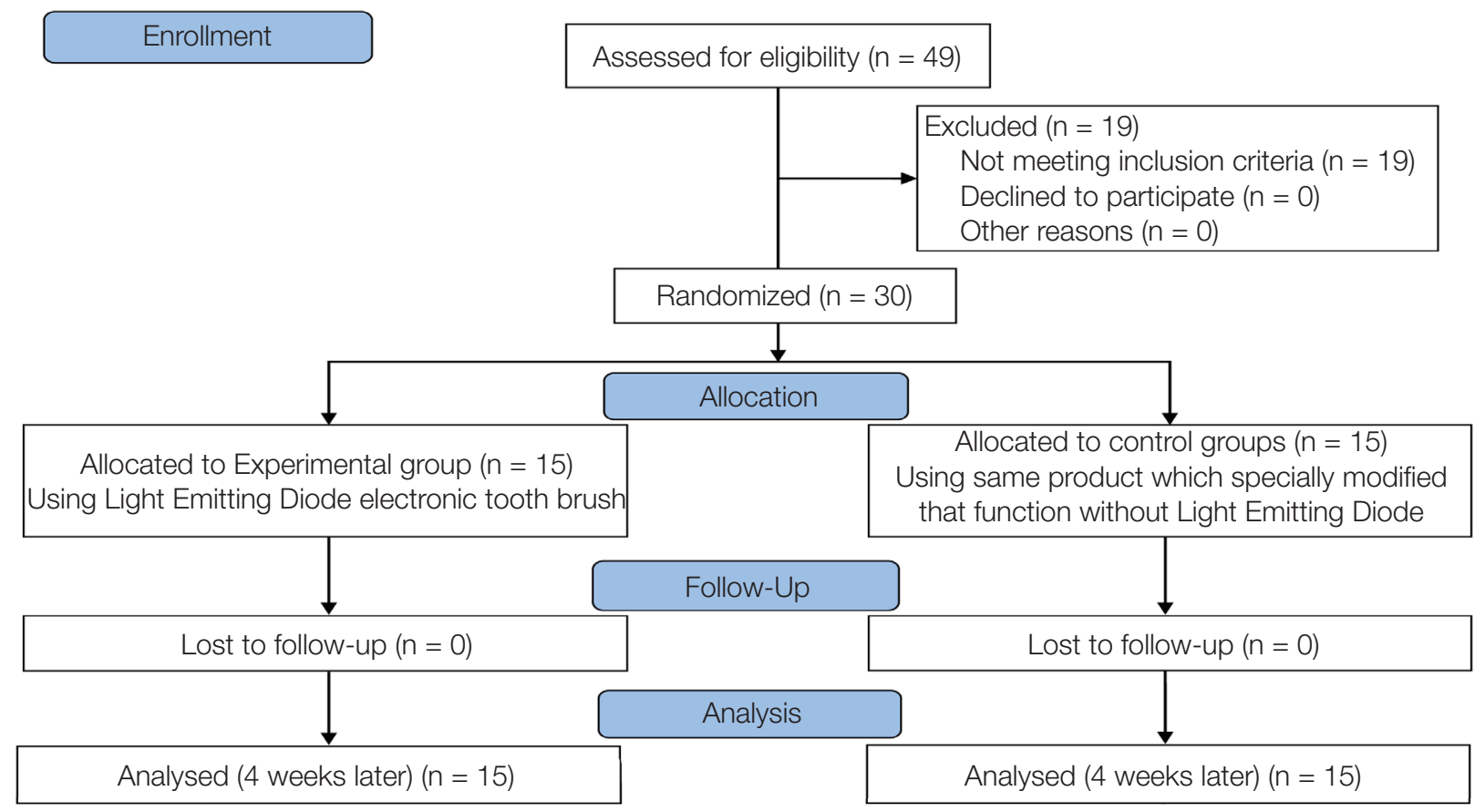

Fig. 1. Consolidated Standards of Reporting Trials (CONSORT) flow diagram for individual randomized, controlled trials of effect of Light Emitting Diode tooth brush.

which specially modified that function without LED. Disclosing solution (GUM Red cote, Sunstar Butler, Chicago, USA) was used for plaque index evaluation. During experimental period, patients didn't used any other self-performed plaque control device, had professional maintenance and only use toothpaste which didn't have advantageous effect on gingival condition. (Closeup menthol fresh, Unilever, Ho Chi Minh, Vietnam)

\section{Clinical parameter}

Patient were evaluated PI and GI. Plaque accumulation was evaluated with PI. This index emphasizes the difference in plaque accumulation in the gingival third of the tooth and tends to overscore the incisal half of the crown, at the expense of the gingival margin. The scoring system is as follows:

$0=$ No plaque;

$1=$ Separate flecks of plaque at the cervical margin of the tooth;
$2=\mathrm{A}$ thin continuous band of plaque (up to one $\mathrm{mm})$ at the cervical margin of the tooth;

$3=\mathrm{A}$ band of plaque wider than one $\mathrm{mm}$ but covering less than one-third of the crown of the tooth;

$4=$ Plaque covering at least one-third but less than two-thirds of the crown of the tooth;

$5=$ Plaque covering two-thirds or more of the crown of the tooth.

Gingivitis was evaluated GI. The gingival index was designed to estimate different degrees of inflammation in marginal gingiva. Severity of inflammatory change is scored from zero to three, as follows:

$0=$ absence of inflammation;

$1=$ mild inflammation; slight change in color and little change in texture;

$2=$ moderate inflammation; moderate glazing, redness, edema, and hypertrophy; bleeding on pressure;

$3=$ severe inflammation; marked redness and hy- 
pertrophy; tendency to spontaneous bleeding; ulceration.

\section{Experimental design}

Clinical parameters (GI, PI) were measured the baseline, 2 weeks and 4weeks later. During experimental period, patients used LED tooth brush and given toothpaste. Patients were requested not to change their lifestyle and toothbrush method. Experimental protocol is described in Fig. 2 and Table 2.

\section{Statistical analysis}

To compare the difference of control group and test group as time goes by, Wilcoxon signed rank test was performed. And to compare of clinical parameter among baseline, 2 weeks and 4 week later in each group, Mann-Whitney test was performed. These analyses were performed by SPSS software (release 18.0, SPSS Inc. Chicago, USA). A $P$ value of $P<0.05$ was considered statistically significant.

\section{Results}

\section{Change of Gingival index (GI)}

The mean GI in experimental group was 1.37 and in control group was 1.28 at baseline. Experimental group showed statistically significant differences at all the time. Control group didn't show significant differences between baseline and 2 weeks, but others showed statistically significance $(P<0.05$, Fig. 3). Lower GI values detected at 2 weeks and 4 weeks later in experimental group than control group $(P<$ 0.05, Fig. 4).

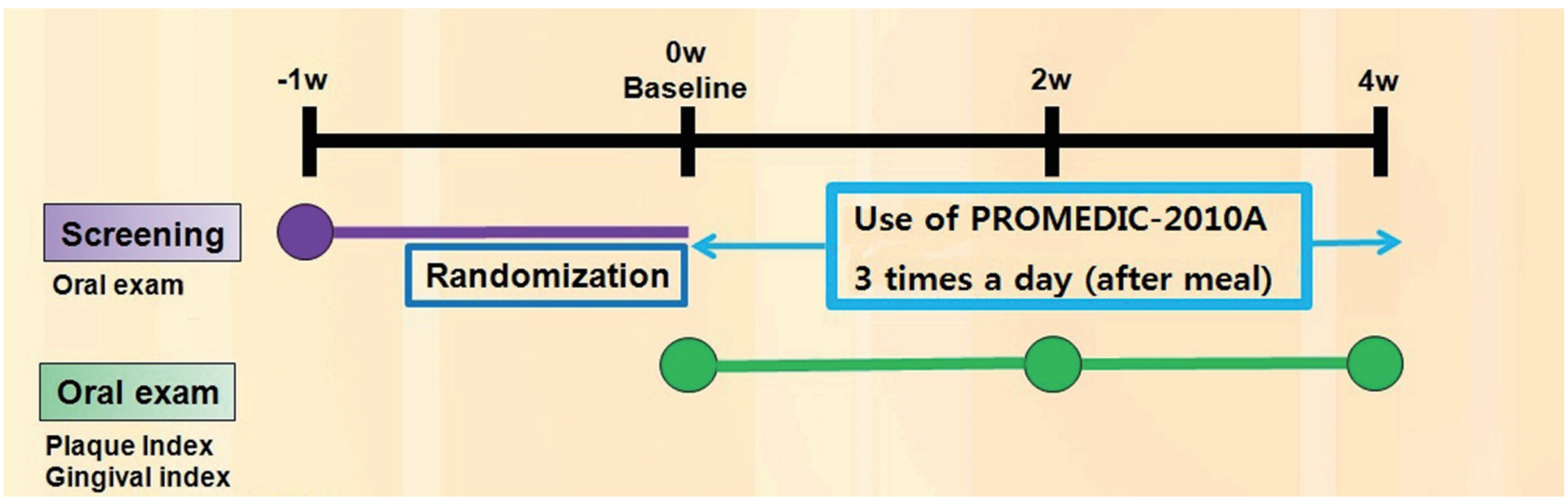

Fig. 2. Experimental Protocol. Screening including oral exam, demographic investigation, medical/dental history, and inclusion/exclusion evaluation.

Table 2. Experimental protocol

\begin{tabular}{|c|c|c|c|c|}
\hline Screening & visit 0 (-1 week) & visit 1 (Baseline) & visit 2 (2 weeks) & visit 3 (4 weeks) \\
\hline Experiment consent & $\mathrm{v}$ & & & \\
\hline Demographic investigation & $\mathrm{v}$ & & & \\
\hline Medical/dental history & $\mathrm{v}$ & & & \\
\hline Inclusion/exclusion evaluation & $\mathrm{v}$ & & & \\
\hline Löe-Silness gingival index (GI) & $\mathrm{v}$ & $\mathrm{v}$ & $\mathrm{v}$ & $\mathrm{v}$ \\
\hline Papillary bleeding index (PI) & $\mathrm{v}$ & $\mathrm{v}$ & $\mathrm{v}$ & $\mathrm{v}$ \\
\hline
\end{tabular}


Gingival index (Gl): Experimental

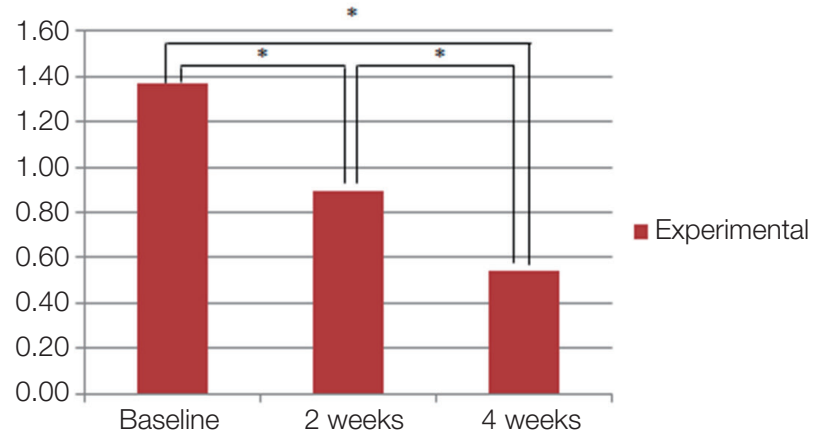

Gingival index (Gl): Control

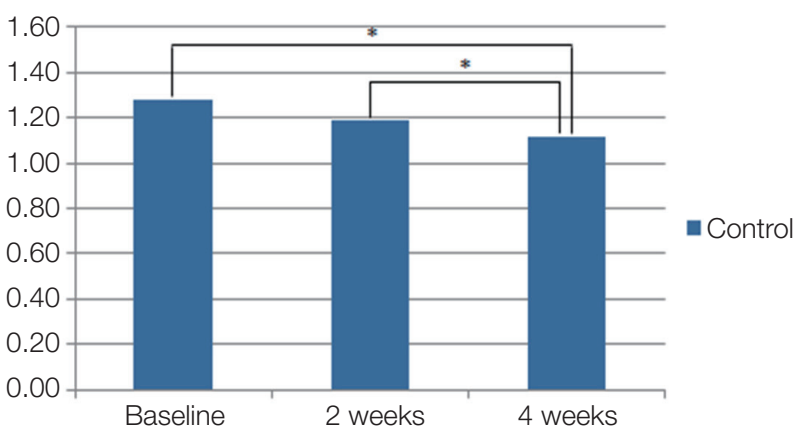

Fig. 3. Change of Löe-Silness gingival index (GI) in experimental and control group. Both groups have statistically significance at all time except between at baseline and 2 weeks in control group.

* Statistically significant difference $(P<0.05)$.

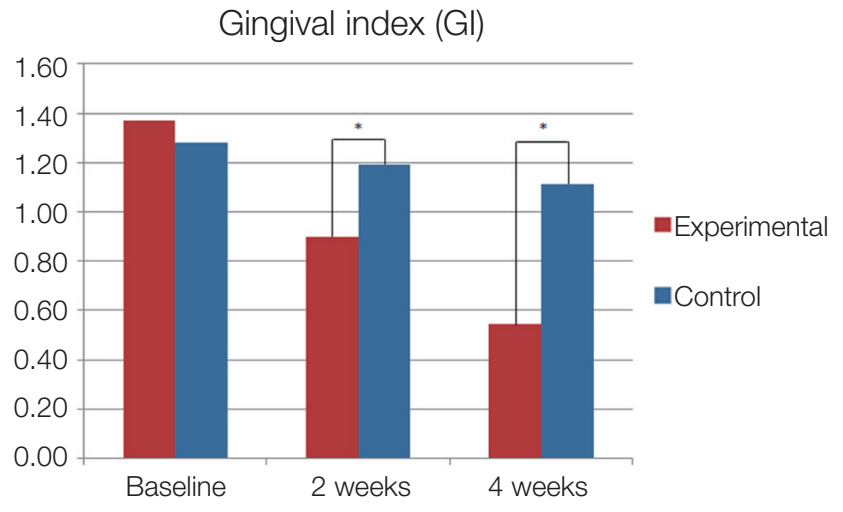

Fig. 4. Compare of Löe-Silness gingival index (GI) change between experimental and control group with time. Both groups showed that reduced GI, but lower GI values detected at 2 weeks and 4 weeks later in experimental group than control group.

* Statistically significant difference $(P<0.05)$.

\section{Change of Plaque index (PI)}

The mean PI in experimental group was 2.59 and in control group was 2.37 at baseline. Experimental group showed statistically significant differences between baseline and 4 weeks later. Control group didn't show significant differences at all the time $(P$ $>0.05$, Fig. 5). Lower PI values detected at 4 weeks later in experimental group than control group, but not statistically significant $(P>0.05$, Fig. 6).

\section{Discussion}

Among the self-performed plaque control methods, daily use of a toothbrush is the most depend-
Plaque index (PI): Experimental

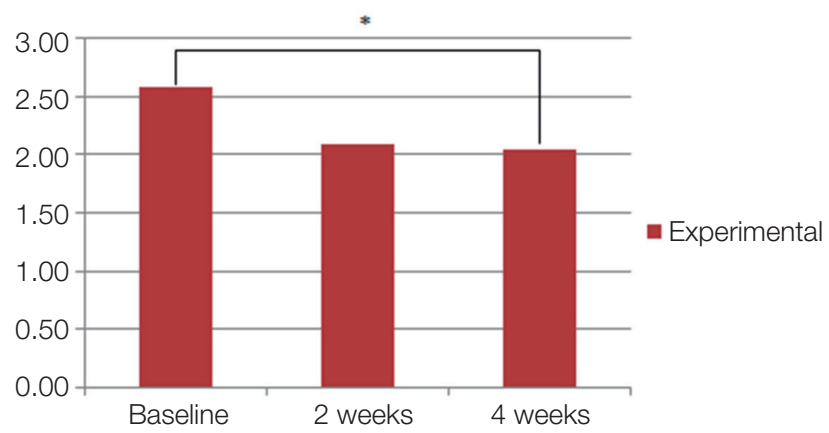

Plaque index (PI): Control

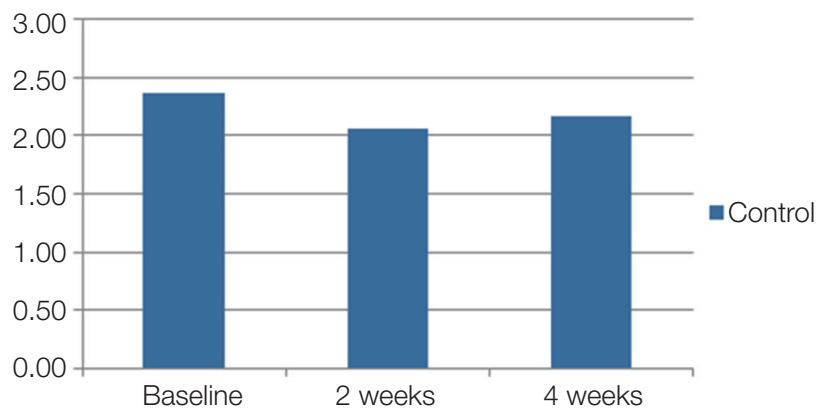

Fig. 5. Change of Turesky-Quigley-Hein plaque index (PI) in experimental and control group. Statistically significant difference was shown between baseline and at 2 weeks later.

* Statistically significant difference $(P<0.05)$. 


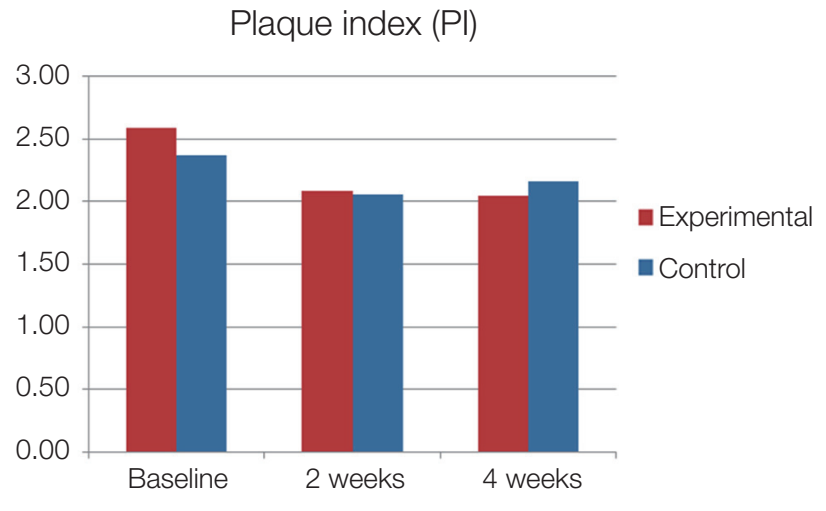

Fig. 6. Compare of Turesky-Quigley-Hein plaque index (PI) change between experimental and control group with time. Lower PI values detected at 4 weeks later in experimental group than control group, but not statistically significant.

able way of achieving oral health benefits. Löe et al. reported that the time necessary to develop gingivitis varied from ten to twenty-one days, and institution of oral hygiene resulted in healthy gingival conditions and re-establishment of the original bacterial flora. ${ }^{10}$

In present study, patients were requested not to change their lifestyle and toothbrush method. And also they didn't used any other self-performed plaque control device and had professional maintenance during experimental period. The reason is to eliminate the possibility of the change of GI or PI by scaling and oral hygiene institution and to evaluate only effect of LED.

In recent years, several reports on the benefits of using LEDs operating at several wavelengths, both in vitro and in vivo, for both normal and pathologic conditions have been published. Lee et al. reported that blue and red LED phototherapy is an effective, safe, pain-free, and easy-to-perform treatment for mild to moderately severe acne vulgaris. ${ }^{11}$ Leticia et al. reported that using infra-red LED to patient who treated with chemotherapy was a safe and effective method for preventing oral mucositis. ${ }^{12}$ Whelan et al. reported that the NASA LED effects the expression of genes involved in wound healing and possibly pain modulation thus enhancing the healing process. ${ }^{13}$ De Sousa reported that The use of green and red LED light is effective in increasing fibroblastic proliferation. ${ }^{14}$

The toothbrush using in present study had red LED and white LED. As described before, the red LED penetrates deep into the skin and can be absorbed by the human cells. The red radiation from LEDs has been reported effective for wound healing, pain relief, skin rejuvenations, and curing inflammation. ${ }^{15-18}$ The white LED was combination of blue, red, and green light sources. These reports were related with our research, using toothbrush with LED decrease gingival inflammation.

In present study, GI decreased statistically significance after 2 weeks and 4 weeks in both groups. The results effected by vibration of electronic toothbrush. However, compare of GI change between experimental and control group, lower GI values detected at 2 weeks and 4 weeks later in experimental group than control group. The result supported that LED effected to decreasing GI.

Compare of PI change between experimental and control group didn't show statistically significance. It seems like that LED didn't effect to reducing plaque accumulation. However, change of PI between at baseline and at 4 weeks showed statistically significance and decreasing consistently. It was able to infer a conclusion that using toothbrush with LED for a long time can show significant change of PI.

There are a few limitations in the present study. The sample size is quite small to show the statistical power, and the short period of research. Further comparative studies with larger sample size should be conducted besides the longer period of research, so as to increase the scientific and statistical power.

\section{Conclusion}

Based on these results and within the limits of this study, the electronic toothbrush with LED could reducing gingivitis in a short period and infer that decreasing plaque accumulation in a long period. However, longer research period and larger sample size will be needed to draw more definite conclusions on the reliability of toothbrush with LED. 


\section{ORCID}

Sung-Jo Lee http://orcid.org/0000-0002-7834-209X

\section{References}

1. Becker W, Becker BE, Berg LE. Periodontal treatment without maintenance. A retrospective study in 44 patients. J Periodontol 1984;55:505-9.

2. Lindhe J, Westfelt E, Nyman S, Socransky SS, Haffajee AD. Long-term effect of surgical/nonsurgical treatment of periodontal disease. J Clin Periodontol 1984;11:448-58.

3. Silverstone LM, Featherstone MJ. A scanning electron microscope study of the end rounding of bristles in eight toothbrush types. Quintessence Int 1988;19:87-107.

4. Hawkins D, Abrahamse H. Phototherapy-a treatment modality for wound healing and pain relief. African J Biomed Res 2007;10:99-109.

5. Wong-Riley MT, Bai X, Buchmann E, Whelan HT. Light-emitting diode treatment reverses the effect of TTX on cytochrome oxidase in neurons. Neuroreport 2001;12:3033-7.

6. Whelan HT, Connelly JF, Hodgson BD, Barbeau L, Post AC, Bullard G, Buchmann EV, Kane M, Whelan NT, Warwick A, Margolis D. NASA lightemitting diodes for the prevention of oral mucositis in pediatric bone marrow transplant patients. J Clin Laser Med Surg 2002;20:319-24.

7. Whelan HT, Houle JM, Donohoe DL, Bajic DM, Schmidt MH, Reichert KW, Weyenberg GT, Larson DL, Meyer GA, Caviness JA. Medical applications of space light-emitting diode technology - space station and beyond. AIP Conference Proceedings 1999;458:3-16.

8. Whelan HT, Smits RL Jr, Buchman EV, Whelan NT, Turner SG, Margolis DA, Cevenini V, Stinson H, Ignatius R, Martin T, Cwiklinski J, Philippi AF, Graf WR, Hodgson B, Gould L, Kane M, Chen G, Caviness J. Effect of NASA light-emitting diode irradiation on wound healing. J Clin Laser Med Surg 2001;19:305-14.

9. Whelan HT, Buchmann EV, Whelan NT, Turner SG, Cevenini V, Stinson H, Ignatius R, Martin T,
Cwiklinski J, Meyer GA, Hodgson B, Gould L, Kane M, Chen G, Caviness J. NASA light emitting diode medical applications from deep space to deep sea. AIP Conference Proceedings 2001;552:35-45.

10. Löe H, Theilade E, Jensen SB. Experimental gingivitis in man. J Periodontol 1965;36:177-87.

11. Lee SY, You CE, Park MY. Blue and red light combination LED phototherapy for acne vulgaris in patients with skin phototype IV. Lasers Surg Med 2007;39:180-8.

12. Lang-Bicudo L, Eduardo Fde P, Eduardo Cde P, Zezell DM. LED phototherapy to prevent mucositis: a case report. Photomed Laser Surg 2008;26: 609-13.

13. Whelan HT, Buchmann EV, Dhokalia A, Kane MP, Whelan NT, Wong-Riley MT, Eells JT, Gould LJ, Hammamieh R, Das R, Jett M. Effect of NASA light-emitting diode irradiation on molecular changes for wound healing in diabetic mice. J Clin Laser Med Surg 2003;21:67-74.

14. de Sousa AP, Santos JN, Dos Reis JA Jr, Ramos TA, de Souza J, Cangussú MC, Pinheiro AL. Effect of LED phototherapy of three distinct wavelengths on fibroblasts on wound healing: a histological study in a rodent model. Photomed Laser Surg 2010;28:547-52.

15. Baez F, Reilly LR. The use of light-emitting diode therapy in the treatment of photoaged skin. J Cosmet Dermatol 2007;6:189-94.

16. Barolet D. Light-emitting diodes (LEDs) in dermatology. Semin Cutan Med Surg 2008;27:227-38.

17. Eells JT, DeSmet KD, Kirk DK, Wong-Riley M, Whelan HT, Ver Hoeve J, Nork TM, Stone J, Valter K. Photobiomodulation for the treatment of retinal injury and retinal degenerative diseases. Proceedings of Light-Activated Tissue Regeneration and Therapy Conference 2008:39-51.

18. Erdle BJ, Brouxhon S, Kaplan M, Vanbuskirk J, Pentland AP. Effects of continuous-wave (670-nm) red light on wound healing. Dermatol Surg 2008;34: 320-5. 


\section{발광 다이오드(Light Emitting Diode) 전동칫솔의 치은염에 대한 효과: 무작위 배정 임상시험}

\section{이성조*}

단국대학교 치과대학 치주과학교실

목적: 이 논문의 목적은 발광 다이오드(Light Emitting Diode(LED))의 유무에 따른 전동칫솔의 항치태 및 항치은염 효 과를 치은염 및 경도의 치주염 환자에서 관찰하는 것이었다.

연구 재료 및 방법: 30 명의 환자를 실험군, 대조군으로 각각 15 명씩 나누어 실험을 진행하였다. 실험군은 정상 작동 의 LED 전동칫솔을 사용하였고 대조군은 LED가 나오지 않도록 개조된 동일 제품의 전동칫솔을 사용하였다. 기 준(Baseline), 2주, 4주 후의 임상지표(Löe-Silness gingival index (GI), Quigley-Hein plaque index (PI))를 측정하여 Wilcoxon signed rank test, Mann-Whitney test를 통해 통계적 분석을 시행하였다.

결과: 실험군과 대조군 간의 시간에 따른 GI의 변화는 두 군 모두 시간에 따른 감소를 나타내었으나, 2주, 4 주차에서 유 의한 차이를 나타내었다. PI는 4주차에서 실험군에서 대조군보다 낮은 수치를 나타내었는데, 통계적으로 유의한 차이는 아니었다.

결론: 본 연구에서 $\mathrm{LED}$ 가 장착된 전동 칫솔은 단기간의 연구에서 치은염의 감소효과를 보였고, 장기간의 관찰 시 치태 의 축적을 감소시킬 수 있다 추측할 수 있었다.

(구강회복응용과학지 2017;33(2):119-26)

주요어: 칫솔질; 광선요법; 저출력 광선 요법; 레이저

*교신저자: 이성조

(31116) 충남 천안시 동남구 단대로 119 단국대학교 치과대학 치주과학교실

Tel: 041-550-0263 | Fax: 0303-3442-7364 | E-mail: periolee85@gmail.com

접수일: 2017년 5월 23일 | 수정일: 2017년 6월 3일 | 채택일: 2017년 6월 9일 